\title{
Zooplankton diversity of a protected and vulnerable wetland system in southern South America (Llancanelo area, Argentina)
}

\author{
D. Sabina D’Ambrosio • María C. Claps • Adriana García
}

Received: 8 October 2015/Accepted: 1 February 2016/Published online: 13 February 2016

(C) The Author(s) 2016. This article is published with open access at Springerlink.com

\begin{abstract}
In arid regions, climatic conditions exert a great control on the aquatic systems present, but recent changes in climate have produced an enhanced salinization of the aquatic environments located there. Consequently, a major reduction in biodiversity would be expected in those wetlands that were originally fresh water. Salinity is a principal cause of reduced biodiversity particularly in zooplankton because few of those species can adapt to the salt pressure of saline environments. Therefore, the aim of this study was to gain essential information on the diversity of aquatic invertebrates in Llancanelo basin by focussing the analysis on the zooplankton community and exploring seasonal and spatial differences in the zooplankton assemblages of this vulnerable wetland system within an arid region of Argentina. Seasonal samples were taken at nine sites in the basin (a shallow lake, 4 springs, streams, and the Malargüe River). A total of 45 species were identified. The zooplankton abundance in the lake displayed a clear seasonal contrast and was higher than that recorded in the springs and lotic environments. Boeckella poopoensis, Fabrea salina, and Brachionus plicatilis predominated in the lake, indicating their halophilia. The presence of the crustaceans Alona sp., Macrocyclops albidus, and Paracyclops fimbriatus was restricted to the springs; whereas Notholca labis and Notholca squamula were found only in running water. The zooplankton species richness in the Llancanelo area is low because of both the salt content in the lake and the irregularity of freshwater entry in all locations during the annual cycle.
\end{abstract}

Keywords Zooplankton $\cdot$ Structure $\cdot$ Wetland system $\cdot$ Salinization $\cdot$ Ramsar site

\section{Introduction}

Abiotic and biotic influences exert a control on the structure and dynamics of zooplankton so as to determine the distribution and abundance of the species (Gyllström and Hansson 2004). In saline lakes in particular, the

\footnotetext{
D. S. D’Ambrosio ( $₫)$

Instituto Argentino de Nivología, Glaciología y Ciencias Ambientales (CCT-CONICET Mendoza), 330, Av. Ruíz Leal s/n, Parque Gral. San Martín, Mendoza 5500, Mendoza, Argentina

e-mail: sabina.dambrosio@gmail.com

M. C. Claps

Instituto de Limnología Dr. Raúl A. Ringuelet (CCT-CONICET La Plata, FCNyM UNLP), Boulevard 120 y 62 (1900),

La Plata, Buenos Aires, Argentina

A. García

GeoQuEST, School of Earth and Environmental Sciences, University of Wollongong, Wollongong, NSW 2522, Australia
} 
biodiversity of the zooplankton is low because few species are adapted to salt stress (Derry et al. 2003; Nielsen et al. 2003). Salinity obviously affects an organism's ability to osmoregulate; which physiologic limitation, in turn, restricts the distribution of species by imposing severe alterations in zooplankton structure and abundance at salinities higher than $1.2 \mathrm{~g} \mathrm{~L}^{-1}$ (Schallenberg et al. 2003). In response to an increase in salinity, freshwater zooplankton exhibits a reduction in growth rates and fecundities and an increase in mortality. In contrast, saline-water-adapted clones are characterized by an increased survival under such conditions (Loureiro et al. 2012; Stoks et al. 2014). Differences in the responses of species could also be related to the concentrations of mono- and divalent cations present (Kipriyanova et al. 2007; McCulloch et al. 2008). Williams (1998) and Wen et al. (2005), among others, have suggested that the structure of a community in a saline lake is dictated by a combination of parameters in addition to salinity-those including dissolvedoxygen concentration, ionic composition, $\mathrm{pH}$, hydrologic patterns, and biotic interactions. The majority of the conditions that influence saline lakes could also be relevant in other freshwater environments located in the same basin with an equivalent previous climatic history and similar human interventions (Kaya et al. 2010). The knowledge of these saline lakes is still limited with respect to such characteristics as water chemistry and the flora and fauna present. In the particular instance of zooplankton, investigations in semi-arid and arid regions of the world have thus far been limited (Shiel et al. 2006); though in the last decade the studies performed in China (Wen et al. 2005), in Australia (Timms 2009), in Chile (De los Ríos 2005; De los Ríos and Contreras 2005; De los Ríos Escalante and Gajardo 2010), and in the pampean region of Argentina (Echaniz et al. 2006; Vignatti et al. 2007; Battauz et al. 2013) can be mentioned, among others.

Aquatic ecosystems are sensitive to climatic change (Williamson et al. 2009) - there, principally in smaller bodies of water and in environments involving elongated or convoluted shorelines (Mason et al. 1994) - to land use in general, and to the introduction of exotic species that impact in different ways depending on the particular geographical location (Heino et al. 2009). In Argentina, these effects would be even more pronounced in those systems lying within the so-called arid diagonal (Bruniard 1982)—it being surrounded by contrasting climatic and phytogeographic regions both to the south and to the north. In this arid zone, rainfall is usually low and global warming has recently led to a consequent decrease in snowfall and a gradual decline in the glaciers constituting the main source of water for the aquatic environments. In recent decades, these wetlands have been retracting, partly because of that decline in snowfall but also as a result of the variation in precipitation in general owing to the interannual or periodical fluctuations caused by the El-Niño-SouthernOscillation (ENSO) phenomenon (Isla et al. 2005). In this region, a warm ENSO phase occurs when a westerly flow of dry air causes a warm, dry summer. Under opposite conditions of temperature and wind direction, a cold-ENSO phase occurs (Vuille et al. 2000; Villalba 2007). This tropical Pacific phenomenon mainly oscillates over a period of 3-6 years (Diaz and Markgraf 2000). Other relevant impacts on the area have been the diversion of water for irrigation, the exploitation of oil reserves around the lake, fishing, and the introduction of exotic species that undermine the continuity of sustainability in the diagonal (Ramsar 2002).

Since, in the wetlands of the Llancanelo basin, the salinity will likely increase as a result of the warmer and drier climate, the salt stress thus produced would provoke a decline in biodiversity (Tavsanoglu et al. 2015) along with subsequent modifications in the function of the ecosystems involved. The objective of this investigation was therefore to enhance our present knowledge of the diversity of aquatic invertebrates in the Llancanelo area, with a particular focus on the zooplankton community and an aim at exploring the seasonal and spatial differences in those assemblages in response to the present environmental conditions within the basin. These findings are intended to provide appropriate baseline data for future determinations of possible species replacements or structural modifications in the zooplankton community as a consequence of global climatic changes.

\section{Materials and methods}

Study area

The Llancanelo basin is located about $70 \mathrm{~km}$ east of the Andes mountain range in the southwest of the Mendoza province, Argentina $\left(35^{\circ} 00^{\prime}-36^{\circ} 30^{\prime} \mathrm{S}, 68^{\circ} 30^{\prime}-70^{\circ} 00^{\prime} \mathrm{W}\right)$ at 1,330 meters above sea level. The basin is 
endorheic, having developed within the Huarpes depression in the northern section of the Payenia Volcanic Province (Ramos and Folguera 2011).

This basin is situated in an arid zone, receiving less than $250 \mathrm{~mm}$ per year of rain or snowfall with evaporation thus dominating over precipitation. The basin consists of that main saline lake along with freshwater environments; the latter as both permanent and ephemeral watercourses, groundwater, and springs. The main water source is from snowmelt during the spring with the Malargüe River being the principal tributary.

Llancanelo Lake and the surrounding springs constitute the main wetlands within this arid diagonal zone of the country. The large number of avian species that inhabit, nest, and have other uses for this portion of their migration routes within these aquatic ecosystems (Darrieu et al. 1989; Sosa 1995, 1999; Blendinger and Álvarez 2002) prompted the creation of the Provincial Natural Reserve and the declaration of a Ramsar-Site Conservation Wetland (Blanco 1999). To date, the studies in the Llancanelo area have been related to birds (Sosa 1995; Blendinger and Álvarez 2002), ostracods (D'Ambrosio et al. 2015), benthic macroinvertebrates (Ciocco and Scheibler 2008; Scheibler and Ciocco 2011, 2013), and plankton and phytobenthos (Peralta and Fuentes 2005), but the last of these was restricted to the Carilauquen Spring.

Sampling sites

Nine sites-constituting lotic, lentic, temporary, and permanent ecosystems-were sampled for zooplankton analyses (Fig. 1). The environment at each site was sampled in a single, fixed location during each season. Llancanelo's total area is $\sim 28,000$ ha, with large changes in that figure on the scale of months, years, or decades (Isla et al. 2005). The Malargüe River originates in the Andes Mountains at $2500 \mathrm{~m}$ above sea level, receiving numerous tributaries as it flows to Llancanelo Lake, with a maximum discharge in the spring and summer (mean $29 \mathrm{~m}^{3} \mathrm{~s}^{-1}$ ). The El Chacay and El Mocho streams originate in the Andes and flow eastward, joining the Malarguie River close to the lake. The delta of the Malargüe River, located at the northwest perimeter of the lake, is formed from water from the aforementioned streams. The delta is developed in a lowland area and, as a result of marked seasonal fluctuations can be temporary. The lake itself is a shallow saline body of water of but $0.3 \mathrm{~m}$ of mean depth, though deeper sections can reach up to $1.70 \mathrm{~m}$. The lake is fed by both permanent and ephemeral watercourses, groundwater, and cold and warm springs, with all those inputs being of freshwater. As stated above, the principal water source for the lake (and indeed for the entire basin) is from snowmelt during the spring, and mainly via the Malargüe River. The water of the springs and lake contains principally calcium sulfate and sodium chloride (Ostera and Dapeña 2003; Peralta and Fuentes 2005; Scheibler and Ciocco 2011). The high temperatures and scarce rainfall produce salt flats in the shallowest sections of the lake and on the southern and southeastern sides. The springs are fed by groundwater and form extensive wetlands, usually connected to the lake by small streams. Carapacho is the only warm spring in the area, with a temperature at around $19-20{ }^{\circ} \mathrm{C}$ that is constant during the four seasons. The mean water depth of the springs is only $0.30 \mathrm{~m}$; except for Carapacho, the deepest one, at over $4.00 \mathrm{~m}$ (Fig. 1; Table 1).

Water and zooplankton sampling

Samples were taken seasonally throughout 2010. At each sampling point, in situ measurements of physical and chemical variables (temperature, $\mathrm{pH}$, conductivity, salinity, and dissolved-oxygen concentration) were obtained with a Horiba U-10 multimeter and the mean values for the data subsequently calculated. The samples were collected by means of a suction pump (4100 $\mathrm{L} \mathrm{h}^{-1}$ maximum flow). A volume of $30 \mathrm{~L}$ (in lentic environments) or $50 \mathrm{~L}$ (in lotic environments) was pumped and passed through a plankton net of $35-\mu \mathrm{m}$ mesh size. Samples were fixed with $4 \%(\mathrm{v} / \mathrm{v})$ formaldehyde in the field. The quantitative analysis for estimating the abundance of protozoans and rotifers was performed with a Sedgwick-Rafter chamber and an Olympus CX $31^{\mathrm{TM}}$ compound light microscope, while the crustaceans were enumerated in a 10-ml Bogorov chamber under an Olympus SZ $61^{\mathrm{TM}}$ stereo zoom microscope. After an initial mixing by magnetic stirring, repeated subsamples were counted. The coefficient of variation- $\mathrm{CV}=$ (standard deviation/mean) $\times 100$-at values always lower than $20 \%$ was used for abundance comparisons between dominant species in paired samples. Zooplankters were identified the genus or species level except for the bdelloids and juvenile copepods. The protozoans were identified according to Grospietsch (1972) and Foissner et al. (1999), among other authors. 


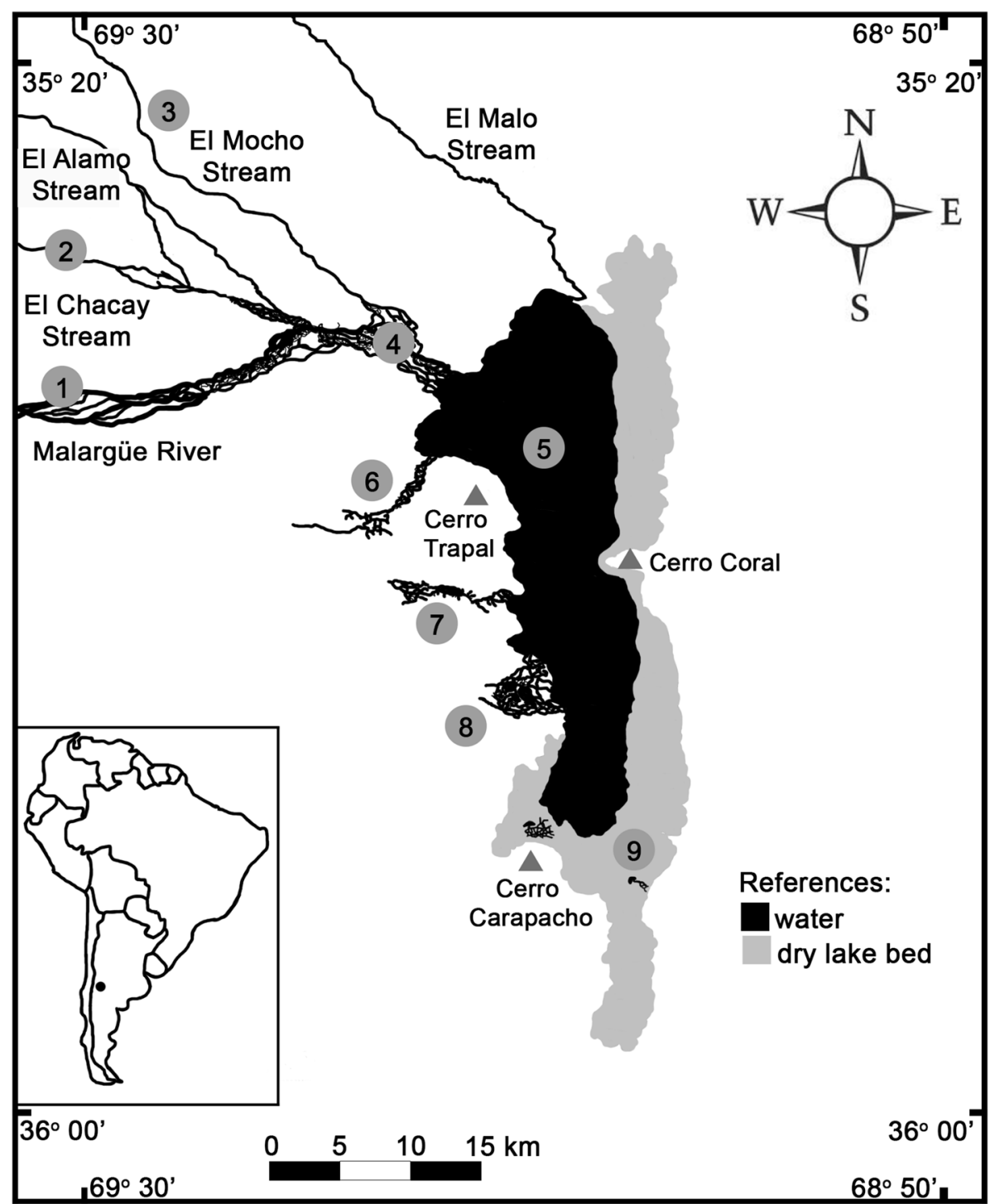

Fig. 1 Location of the sampling sites. 1 Malargüe River, 2 El Chacay Stream, 3 El Mocho Stream, 4 Malargüe River delta, 5 Llancanelo Lake, 6 Los Menucos Spring, 7 Carilauquen Spring, 8 Carapacho Warm Spring, 9 La Porteña Spring

The rotifer identification was based on Koste (1978) and Segers (1995). Crustaceans were identified based on Reid (1985), Bayly (1992), Smirnov (1996), and Wells (2007).

Statistical analysis

The Olmstead-Tukey test was applied to analyze the frequency of occurrence and mean abundance of each species (Sokal and Rohlf 1979). This test plots the abundance of each species (as individuals per liter on the ordinate) versus the frequency of occurrence at each sampling site (as a percent on the abscissa). An average was calculated on both axes that resulted in four categories: frequent and abundant (dominant) species; abundant and infrequent (occasional) species; frequent and scarce (common) species, and infrequent and scarce (rare) species.

The diversity index of Shannon and Wiener $\left(H^{\prime}\right)$ and the evenness $\left(E^{\prime}\right)$ were calculated in order to describe the seasonal relationship between the species richness and the abundance distribution among the species within the environments of the Llancanelo basin. 
Table 1 Geographical characteristics of the sampling sites selected in the Llancanelo basin

\begin{tabular}{|c|c|c|c|c|}
\hline \multirow{2}{*}{$\begin{array}{l}\text { Environment } \\
\text { Lotic and permanent }\end{array}$} & \multirow[t]{2}{*}{ Site number } & \multicolumn{2}{|c|}{$\begin{array}{l}\text { Geographical coordinates } \\
\text { South West }\end{array}$} & \multirow[t]{2}{*}{ Altitude above sea level (m) } \\
\hline & & & & \\
\hline Malargüe River & 1 & $35^{\circ} 32^{\prime} 33.1^{\prime \prime}$ & $69^{\circ} 35^{\prime} 50.7^{\prime \prime}$ & 1483 \\
\hline El Chacay Stream & 2 & $35^{\circ} 28^{\prime} 32.0^{\prime \prime}$ & $69^{\circ} 25^{\prime} 45.5^{\prime \prime}$ & 1357 \\
\hline \multicolumn{5}{|l|}{ Lotic and temporary } \\
\hline El Mocho Stream & 3 & $35^{\circ} 28^{\prime} 01.1^{\prime \prime}$ & $69^{\circ} 18^{\prime} 41.8^{\prime \prime}$ & 1346 \\
\hline Malargüie River delta & 4 & $35^{\circ} 31^{\prime} 50.0^{\prime \prime}$ & $69^{\circ} 12^{\prime} 53.3^{\prime \prime}$ & 1344 \\
\hline \multicolumn{5}{|l|}{ Lentic, permanent and saline } \\
\hline Llancanelo Lake & 5 & $35^{\circ} 34^{\prime} 50.82^{\prime \prime}$ & $69^{\circ} 09^{\prime} 14.58^{\prime \prime}$ & 1331 \\
\hline \multicolumn{5}{|l|}{ Lentic, permanent and freshwater } \\
\hline Los Menucos Spring (rheocrene) & 6 & $35^{\circ} 34^{\prime} 59.3^{\prime \prime}$ & $69^{\circ} 14^{\prime} 01.7^{\prime \prime}$ & 1305 \\
\hline Carilauquen Spring (limnocrene) & 7 & $35^{\circ} 39^{\prime} 29.8^{\prime \prime}$ & $69^{\circ} 16^{\prime} 05.9^{\prime \prime}$ & 1341 \\
\hline Carapacho Warm Spring (heleocrene) & 8 & $35^{\circ} 43^{\prime} 43.4^{\prime \prime}$ & $69^{\circ} 11^{\prime} 46.2^{\prime \prime}$ & 1342 \\
\hline La Porteña Spring (limnocrene) & 9 & $35^{\circ} 50^{\prime} 41.6^{\prime \prime}$ & $69^{\circ} 04^{\prime} 12.1^{\prime \prime}$ & 1336 \\
\hline
\end{tabular}

Multivariate-ordination techniques from the CANOCO software (version 4.5) were used to investigate the relationship between species composition and environmental variables in the sampling sites. The environmental variables were standardized (Ter Braak 1986). Because the lengths of the explanatory-variable gradients were short, the method of redundancy analysis was selected over analysis by canonical correspondence, as suggested by ter Braak and Smilauer (1998). The statistical significance of the variation in the parameters and the overall significance of the ordination were tested with the Monte-Carlo permutation test (499 unrestricted permutations; $p<0.01$ ). Only the environmental parameters with variance-inflation factors $<10$ were retained in the analysis because a greater value would indicate a multicolinearity among the variables (ter Braak and Verdonschot 1995).

\section{Results}

Environmental parameters

The water temperature in the lake reflected the marked seasonal pattern in the basin, with values near $25{ }^{\circ} \mathrm{C}$ in the summer and around $0{ }^{\circ} \mathrm{C}$ during the winter. In the springs (other than Carapacho) and the lotic environments, the maximum and minimum mean values also underwent extremes (from 30 to 3 and 27 to $0{ }^{\circ} \mathrm{C}$, respectively). The salinity levels were notably high in the lake, whereas the corresponding values were much lower and without seasonal variation in the springs and the lotic environments. The mean $\mathrm{pH}$ recorded in all of the environments was alkaline, with similar values in the lake and springs (i.e., from 7.6 to 8.8), though somewhat higher in the lotic environments (i.e., from 7.8 to 9.3). The mean percent dissolved oxygen was similar in all the environments, reaching higher than $50 \%$ on both the summer and winter sampling dates (Table 2).

The zooplankton community

A total of 45 species [1 dinoflagellate, 1 foraminifer, 10 testate amoebae, 9 ciliates, 13 rotifers, and 11 crustaceans (4 cladocerans and 7 copepods)] were identified (Table 3).

The species richness was very low in all the environments (Fig. 2). In the lake, the highest mean number of species was recorded in the summer (11 species), while the minimum occurred in the spring ( 2 species). The species richness in the springs was similar during all seasons, attaining maxima in La Porteña in the summer (at 7 species) and in Carapacho in the autumn (at 7 species). In the lotic environments, the lowest number of species was recorded in the summer and winter (at 2 species); whereas, in the delta of the Malarguie River, maxima were observed in the spring and autumn (at 7 species). 
Table 2 Mean and standard deviation of water physicochemical variables measured seasonally in the environments of the Llancanelo basin

\begin{tabular}{lllccc}
\hline Environment & Season & $\mathrm{pH}$ & Water temperature $\left({ }^{\circ} \mathrm{C}\right)$ & Salinity $\left(\mathrm{g} \mathrm{L}^{-1}\right)$ & Dissolved oxygen $\left(\mathrm{mg} \mathrm{L}^{-1}\right)$ \\
\hline River and streams & Spring & $8.7( \pm 0.4)$ & $22.2( \pm 5.6)$ & $0.8( \pm 0.5)$ & $4.6( \pm 2.2)$ \\
& Summer & $8.8( \pm 0.3)$ & $24.2( \pm 2.8)$ & $0.8( \pm 0.3)$ & $9.6( \pm 3.3)$ \\
& Autumn & $8.2( \pm 0.2)$ & $8.6( \pm 2.6)$ & $1.7( \pm 0.8)$ & $2.5( \pm 0.4)$ \\
& Winter & $8.4( \pm 0.2)$ & $1.2( \pm 1.2)$ & $2.1( \pm 1.1)$ & $13.7( \pm 0.8)$ \\
Llancanelo Lake & Spring & $8.2( \pm 0.1)$ & $25.3( \pm 2.7)$ & $18.3( \pm 9.4)$ & $4.0( \pm 1.7)$ \\
& Summer & $8.3( \pm 0.4)$ & $22.4( \pm 3.0)$ & $33.5( \pm 7.5)$ & $7.2( \pm 1.2)$ \\
& Autumn & $7.8( \pm 0.1)$ & $10.8( \pm 2.1)$ & $32.9( \pm 15.4)$ & $2.9( \pm 0.6)$ \\
Springs & Winter & $8.1( \pm 0.1)$ & $1.1( \pm 0.8)$ & $39.7( \pm 6.3)$ & $9.6( \pm 2.2)$ \\
& Spring & $8.3( \pm 0.5)$ & $22.3( \pm 5.5)$ & $1.0( \pm 0.8)$ & $2.9( \pm 0.8)$ \\
& Summer & $8.1( \pm 0.3)$ & $21.9( \pm 0.5)$ & $1.3( \pm 1.2)$ & $8.6( \pm 3.6)$ \\
& Autumn & $8.1( \pm 0.4)$ & $12.2( \pm 6.5)$ & $1.6( \pm 1.2)$ & $2.4( \pm 0.8)$ \\
& Winter & $8.0( \pm 0.3)$ & $10.0( \pm 7.8)$ & $1.5( \pm 1.2)$ & $9.7( \pm 3.0)$ \\
\hline
\end{tabular}

Table 3 Density ranges (individuals $\mathrm{m}^{-3}$ ) of zooplankton species collected seasonally in the environments of the Llancanelo basin (1: <250, 2: 250-2500, 3: 2500-7500, 4: 7500-12,500, 5: 12,500-50,000, 6: 50,000-100,000, 7: >1,500,000)

\begin{tabular}{|c|c|c|c|c|c|c|c|c|c|c|c|c|}
\hline & \multicolumn{4}{|c|}{ Lake } & \multicolumn{4}{|c|}{ Springs } & \multicolumn{4}{|c|}{ River and streams } \\
\hline & $\mathrm{Sp}$ & $\mathrm{Su}$ & $\mathrm{Au}$ & Wi & $\mathrm{Sp}$ & $\mathrm{Su}$ & $\mathrm{Au}$ & $\mathrm{Wi}$ & $\mathrm{Sp}$ & $\mathrm{Su}$ & $\mathrm{Au}$ & Wi \\
\hline \multicolumn{13}{|l|}{ MYZOZOA } \\
\hline Protoperidinium achromaticum (Levander, 1902) & & 7 & & & & & 2 & 2 & & & 1 & \\
\hline \multicolumn{13}{|l|}{ CILIOPHORA } \\
\hline Codonella cratera Leidy, 1887 & & 5 & & & & & & & & & & \\
\hline Cothurnia sp. & & & & & & & & & & & 5 & \\
\hline Euplotes sp. & & 3 & & & & & & & & & & \\
\hline Fabrea salina Henneguy, 1890 & & 5 & 5 & & & 2 & 2 & & & & & \\
\hline Frontonia sp. & & & & & & & 2 & & & & & 2 \\
\hline Paramecium caudatum Ehrenberg, 1833 & & & & & & & & & & & 2 & \\
\hline Spirostomum sp. & & & 3 & & & & & & & & & \\
\hline Teuthophrys trisulca Chatton \& de Beauchamp, 1923 & & 6 & & & & & & & & & & \\
\hline Urotricha sp. & & 5 & & & & & & & & & & \\
\hline \multicolumn{13}{|l|}{ FORAMINIFERA } \\
\hline Ammonia sp. & 1 & & & 3 & 1 & 2 & & 2 & & & & 2 \\
\hline \multicolumn{13}{|l|}{ AMOEBOZOA } \\
\hline Arcella hemisphaerica Perty, 1852 & & & 3 & 4 & & & 5 & 3 & & 3 & 3 & 2 \\
\hline Centropyxis aculeata (Ehrenberg, 1838) & & & & & 2 & & & & & & 2 & \\
\hline Centropyxis ecornis (Ehrenberg, 1841) & & 3 & & & & & & & & & & \\
\hline Cyclopyxis sp. & & & & & 2 & & & & 2 & & & \\
\hline Difflugia acuminata Ehrenberg, 1838 & & & & & & & 3 & & & & & \\
\hline Difflugia corona Wallich, 1864 & & & & 3 & & & & & & & 2 & \\
\hline Difflugia sp. & & & & & & & & 5 & & & & \\
\hline Quadrulella sp. & & & & & 2 & & & & 2 & & & \\
\hline \multicolumn{13}{|l|}{ CERCOZOA } \\
\hline Cyphoderia ampulla (Ehrenberg, 1840) & & & 2 & & & 2 & & 2 & & 1 & 2 & 2 \\
\hline Euglypha acanthophora (Ehrenberg, 1841) & & & & & & & 2 & & & & & \\
\hline \multicolumn{13}{|l|}{ ROTIFERA } \\
\hline Bdelloid sp1 & & 6 & 3 & & & 3 & 3 & 2 & 2 & 2 & 2 & 3 \\
\hline Bdelloid sp2 & & & & & & & & & & & & 2 \\
\hline
\end{tabular}


Table 3 continued

\begin{tabular}{|c|c|c|c|c|c|c|c|c|c|c|c|c|}
\hline & \multicolumn{4}{|c|}{ Lake } & \multicolumn{4}{|c|}{ Springs } & \multicolumn{4}{|c|}{ River and streams } \\
\hline & Sp & $\mathrm{Su}$ & $\mathrm{Au}$ & Wi & Sp & $\mathrm{Su}$ & $\mathrm{Au}$ & Wi & $\mathrm{Sp}$ & $\mathrm{Su}$ & $\mathrm{Au}$ & Wi \\
\hline Bdelloid sp3 & & & & & & & & & & & & 2 \\
\hline Brachionus plicatilis Müller, 1786 & & 6 & 5 & 2 & & 5 & 2 & & & 1 & 1 & \\
\hline Brachionus quadridentatus Hermann, 1783 & & 5 & & & 3 & 3 & & & & & & \\
\hline Brachionus rotundiformis Tschugunoff, 1921 & & & & & & 3 & & & & & & \\
\hline Colurella uncinata (Müller, 1773) & 2 & 3 & 2 & & & & & & & & 1 & 2 \\
\hline Euchlanis dilatata Ehrenberg, 1832 & & & & & & 2 & & & & 2 & & \\
\hline Hexarthra fennica (Levander, 1892) & & & & & & 2 & & & & & & \\
\hline Lecane closterocerca (Schmarda, 1859) & & & & & & & & & 2 & & & \\
\hline Lecane hamata (Stokes, 1896) & & & & & & & 2 & & & & 1 & \\
\hline Lecane luna (Müller, 1776) & & & & & & & 2 & & 1 & 2 & & \\
\hline Notholca acuminata (Ehrenberg, 1832) & & & & & & & & & 2 & & & \\
\hline Notholca labis Gosse, 1887 & & & & & & & & & & & 2 & 2 \\
\hline Notholca squamula (Müller, 1786) & & & & & & & & & & & & 2 \\
\hline \multicolumn{13}{|l|}{ ARTHROPODA } \\
\hline Alona sp. & & & & & 2 & 2 & & & & & & \\
\hline Macrothrix sp. & & & & & & & & & & 1 & & \\
\hline Pseudochydorus globosus (Baird, 1843) & & & & & 2 & & 3 & & 2 & & 2 & 2 \\
\hline Chydorus sphaericus (Müller, 1785) & & & & & & & & & 2 & & & \\
\hline Boeckella poopoensis Marsh, 1906 & 6 & 3 & 3 & 4 & & & & & & & & \\
\hline Apocyclops procerus (Herbst, 1955) & & & & & & & & & 3 & & & \\
\hline Macrocyclops albidus (Jurine, 1820) & & & & & & 2 & 3 & & & & & \\
\hline Metacyclops mendocinus (Wierzejski, 1892) & & & & & 2 & 2 & 2 & 2 & 5 & 2 & 3 & 2 \\
\hline Paracyclops fimbriatus (Fischer, 1853) & & & & & 1 & 2 & 1 & & & & & \\
\hline Attheyella (Delachauxiella) sp. & 4 & 3 & 3 & 4 & 3 & 5 & 3 & & 3 & 1 & 2 & 2 \\
\hline Cletocamptus sp. & & & & & 2 & 1 & & & & & & \\
\hline
\end{tabular}

$S p$ spring, $S u$ summer, $A u$ autumn, $W i$ winter

In the lake, the crustaceans predominated in the spring, as exemplified by the abundance of adults of Boeckella poopoensis. The rotifers were abundant in summer (e.g., Brachionus plicatilis and B. quadridentatus) and autumn (e.g., B. plicatilis). The protozoans were codominant as a result of the numerical contribution of Protoperidinium achromaticum in the summer and of Fabrea salina in the summer and autumn. In the winter, the protozoans prevailed owing to the abundance of certain testate amoebae and Ammonia sp. (Fig. 2).

In the springs, the abundance of two harpacticoid species (Cletocamptus sp. and Attheyella (Delachauxiella) sp.) along with Metacyclops mendocinus made the crustaceans the dominant group during the spring. The rotifers were relevant contributers in the summer because of the predominance of $B$. plicatilis. Finally, the protozoans-mainly Arcella hemisphaerica - became dominant in the autumn and winter (Fig. 2).

In the lotic environments, the crustaceans (M. mendocinus, Attheyella sp., and two chydorids) predominated in the spring, while tychoplanktonic rotifers and cladocerans dominated in the summer. The protozoans (testate amoebae) were relevant contributers in the autumn, while the rotifers (Notholca labis and Notholca squamula) predominated in the winter (Fig. 2).

On the basis of the Olmstead and Tukey test, no particular species was dominant in the lake. The dinoflagellate $P$. achromaticum was occasional and six other species were common (Ammonia sp., A. hemisphaerica, B. plicatilis, Colurella uncinata, Attheyella sp., and B. poopoensis). Eleven species were rare (Fig. 3a). In the springs, five species were dominant, having the highest frequencies as well as densities. One protozoan (Difflugia sp.) and one crustacean (Macrocyclops albidus) were occasional along with five species that were common (P. achromaticum, Ammonia sp., Paracyclops fimbriatus, M. mendocinus, and 

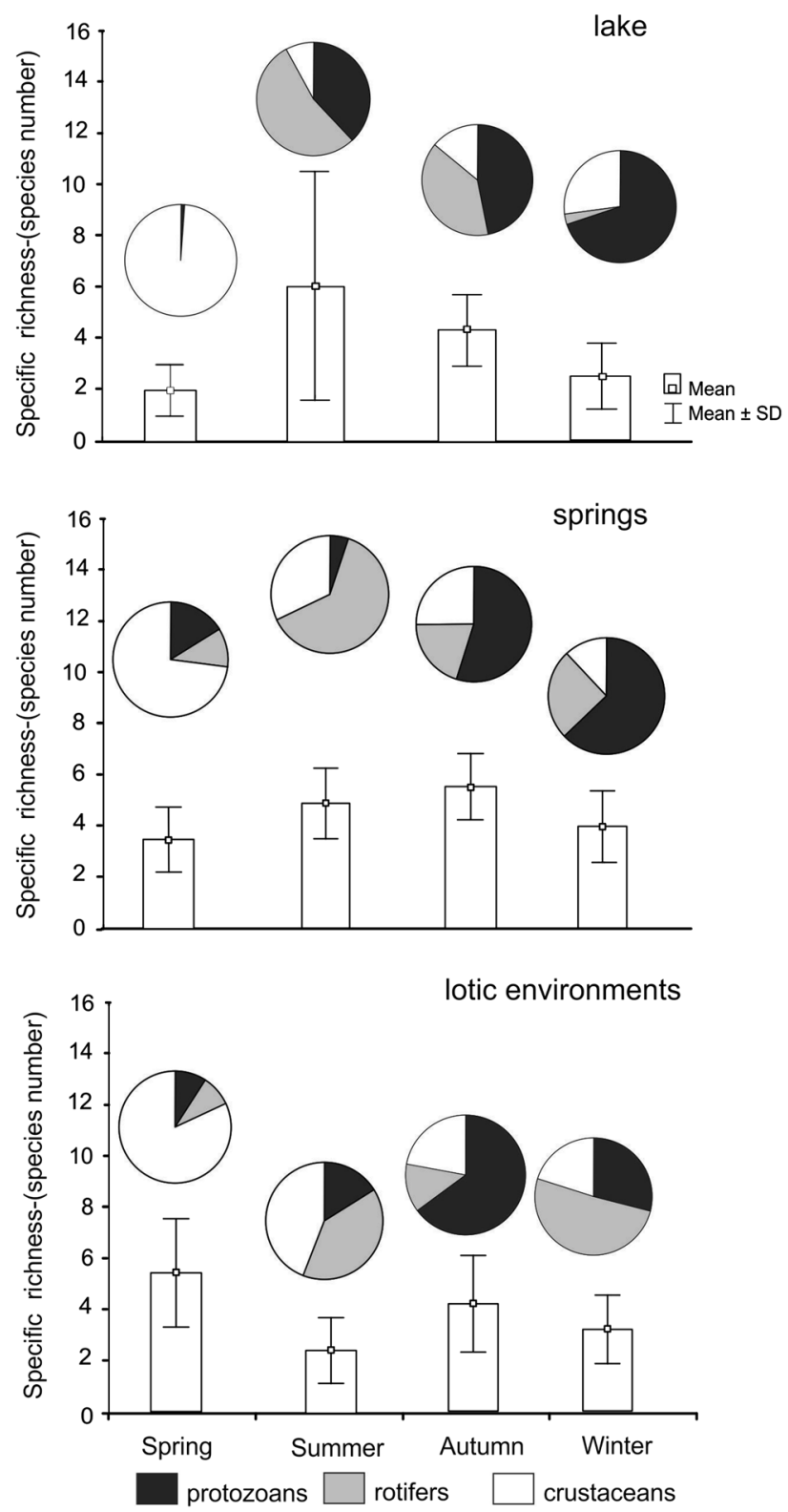

Fig. 2 Zooplankton species richness (bars) and relative abundance of zooplankton groups (protozoans: white, rotifers: grey, crustaceans: black) recorded in the three kinds of environments of the Llancanelo wetland system: the lake, the springs, and the lotic systems. In the springs and lotic systems, the mean values obtained from the stations sampled are included

Pseudochydorus globosus), while 15 species were rare (Fig. 3b). In the lotic environments, five species were dominant and only one occasional. Three rotifers (Euchlanis dilatata, Lecane luna, and N. labis), one foraminifer (Ammonia sp.) and one crustacean ( $P$. globosus) manifested the highest frequency in combination with a low density (common). In these environments, eighteen species were rare (Fig. 3c).

In the lake, the zooplankton abundance showed a clear seasonal contrast, with a maximum in the summer being related to the contribution of $P$. achromaticum and a minimum in the winter. In the springs, a maximum was likewise recorded in the summer with a predominance of saline rotifers, while the lowest abundance occurred in the spring. In the lotic environments, the highest values were observed in the autumn as a result of the dominance of Cothurnia sp. and A. hemisphaerica, whereas the lowest abundance was recorded in the winter. The zooplankton densities registered in the lake in particular were quite variable and higher than in the other two types of aquatic ecosystems (i.e., the springs and the lotic environments). 


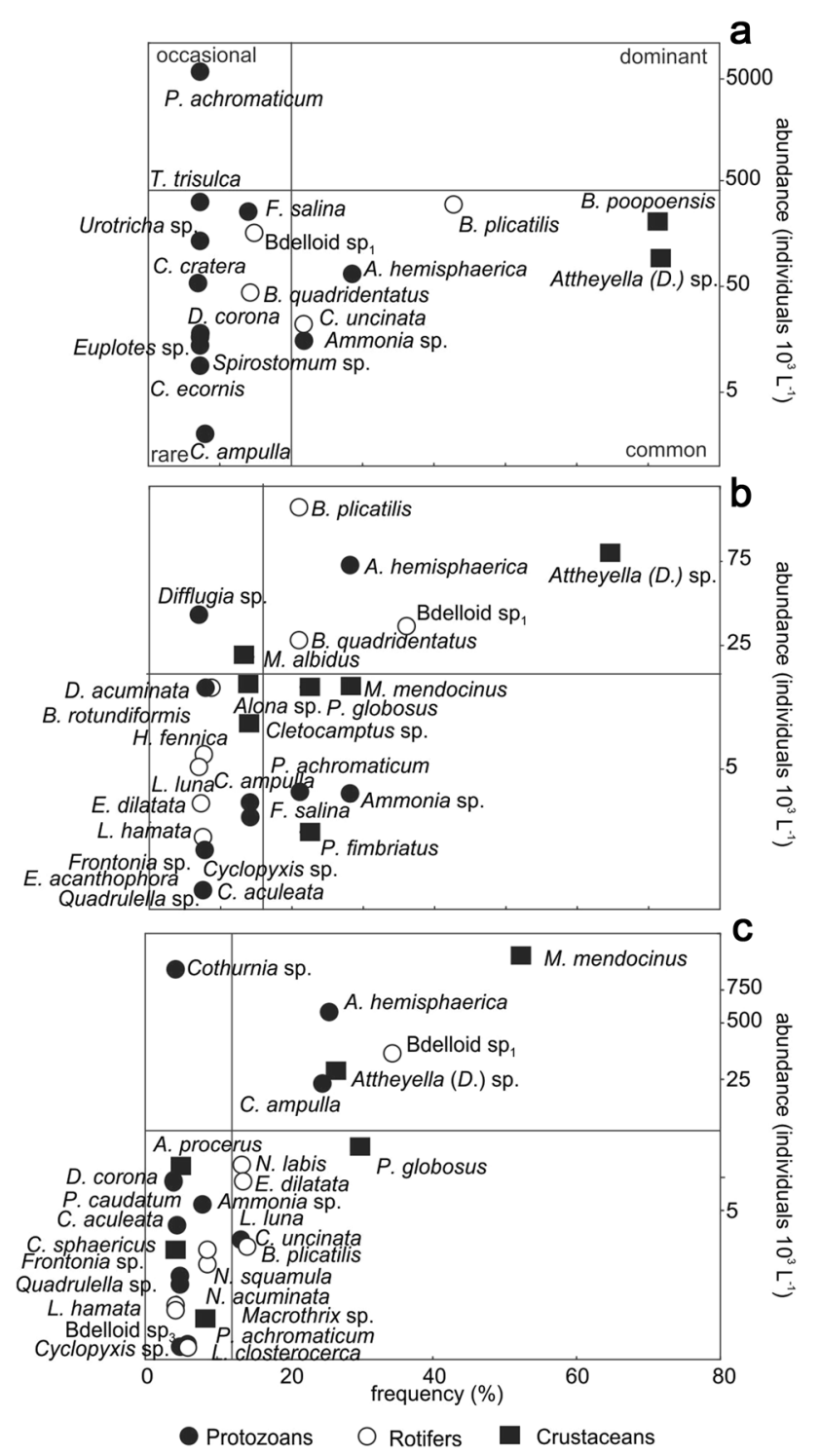

Fig. 3 Species plot (solid circle protozoans, open circle rotifers, solid square crustaceans) according to the Olmstead-Tukey test in the Llancanelo-wetland system during the seasonal sampling period (a Llancanelo Lake, $\mathbf{b}$ the springs, $\mathbf{c}$ the lotic environments)

In general, the diversity and evenness were similar in all the basin environments, though with somewhat higher values in the springs and lotic environments (Fig. 4). The highest values of the diversity index $\left(H^{\prime}\right)$ recorded in the lake were similar to the lowest recorded in the other basin environments. The greatest diversity - specifically in the lake and the lotic environments - was registered in autumn and winter, with those respective seasonal values being 1.57 and 1.55 in the lake and 1.87 and 2.28 , in the lotic environments. These seasonal diversities were characterized by evenly distributed abundances at respective $E^{\prime}$ values of 0.72 and 0.87 in the lake and 0.89 and 0.69 in the lotic environments accompanied by the high respective richnesses of 15 and 13 species. In the springs, the greatest diversity and evenness were observed in the spring and autumn at respective $H^{\prime}$ values of 1.92 and 2.03 and $E^{\prime}$ values of 0.80 and 0.75 in conjunction with a high degree of richness at 11 and 15 species, respectively. The lowest zooplankton diversity and evenness throughout the basin were observed in the lake during the spring and summer at respective $H^{\prime}$ values of 0.53 and 0.73 and $E^{\prime}$ values of 0.38 and 0.29 .

According to the results of redundancy analysis, the first canonical axis and the sum of all canonical axes explained a significant portion of the variance in the zooplankton abundance $(p=0.002 ; p=0.002$, respectively). The first two canonical axes explained $86 \%$ of the cumulative variance. Salinity was correlated 

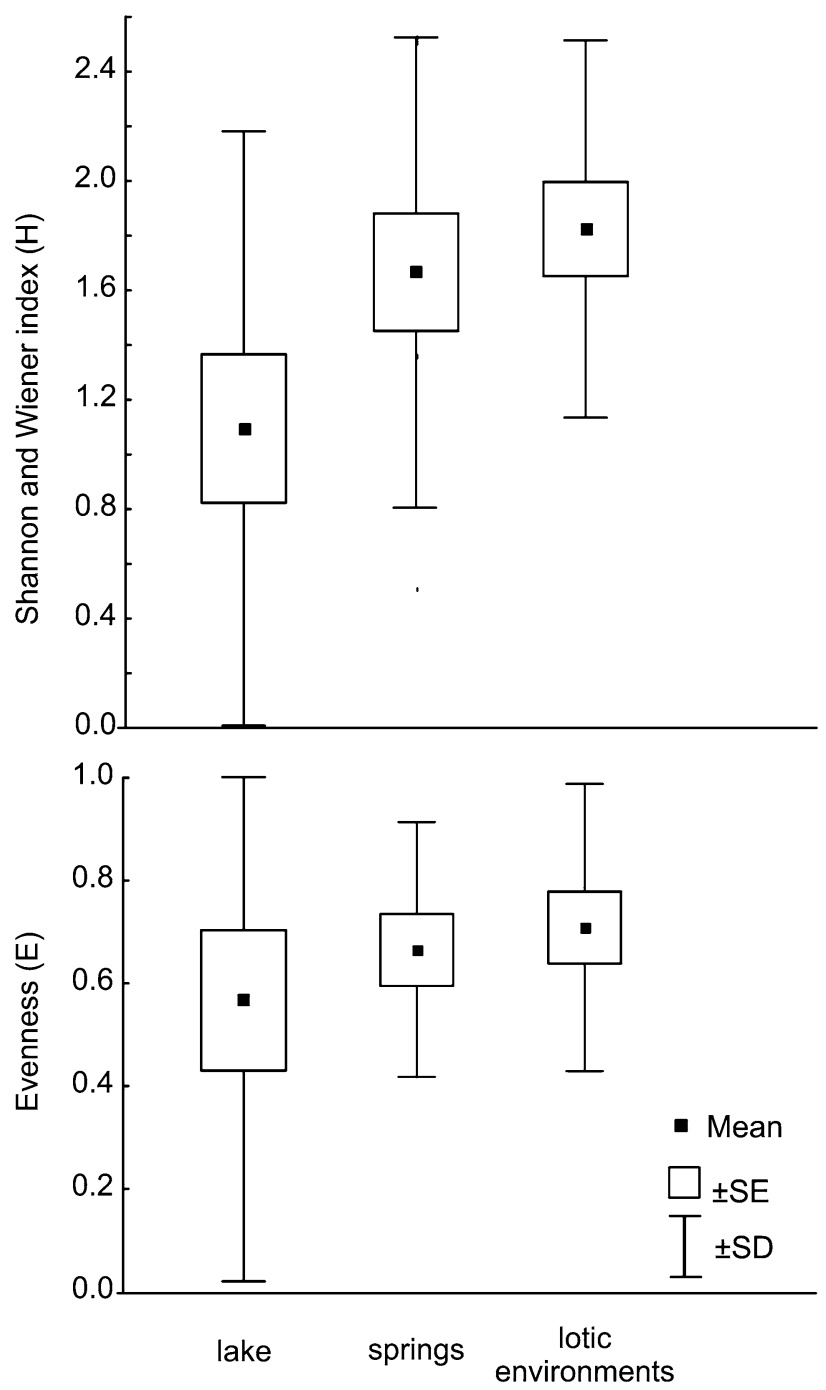

Fig. 4 Box-plot showing the mean and standard deviation of the Shannon-Wiener diversity index and evenness of zooplankton in the three environments that comprise the Llancanelo-wetland system

with the first axis $(R=0.92, p<0.05)$ and $\mathrm{pH}$ and temperature with the second axis $(R=0.44$ and -0.56 , respectively; $p<0.05$ ). All the samples collected in the lake were located in the positive sector of the first axis in relation to the high salinity of this environment and evidently also to the abundant presence of halophilic species such as $F$. salina, $B$. plicatilis, and $P$. achromaticum, among others. The negative sector of the first axis contained all the seasonal samples from the springs and lotic environments. In the positive sector of the second axis-it defined by the highest $\mathrm{pH}$ and lowest temperature values - the samples are representative of mainly the lotic environments and some of the springs characterized by low temperature. The winter sample of Carapacho Spring was the exception owing to its heleocrene nature and consistently warm water. The majority of the samples obtained in the springs were located in the negative sector of the second axis (Fig. 5). All of the environments had exclusive members: B. poopoensis, Codonella cratera, Spirostomum sp., Teuthophrys trisulca, Urotricha sp., and Centropyxis ecornis were representative of the lake, indicating those species' affinities with this shallow and saline environment; whereas M. albidus, P. fimbriatus, Cletocamptus sp., Euglypha acanthophora, Brachionus rotundiformis, and Hexarthra fennica were characteristic of the springs. Finally, species of Notholca and Cothurnia sp., along with Paramecium caudatum, Macrothrix sp., and M. mendocinus were representative of running water (Fig. 6). 


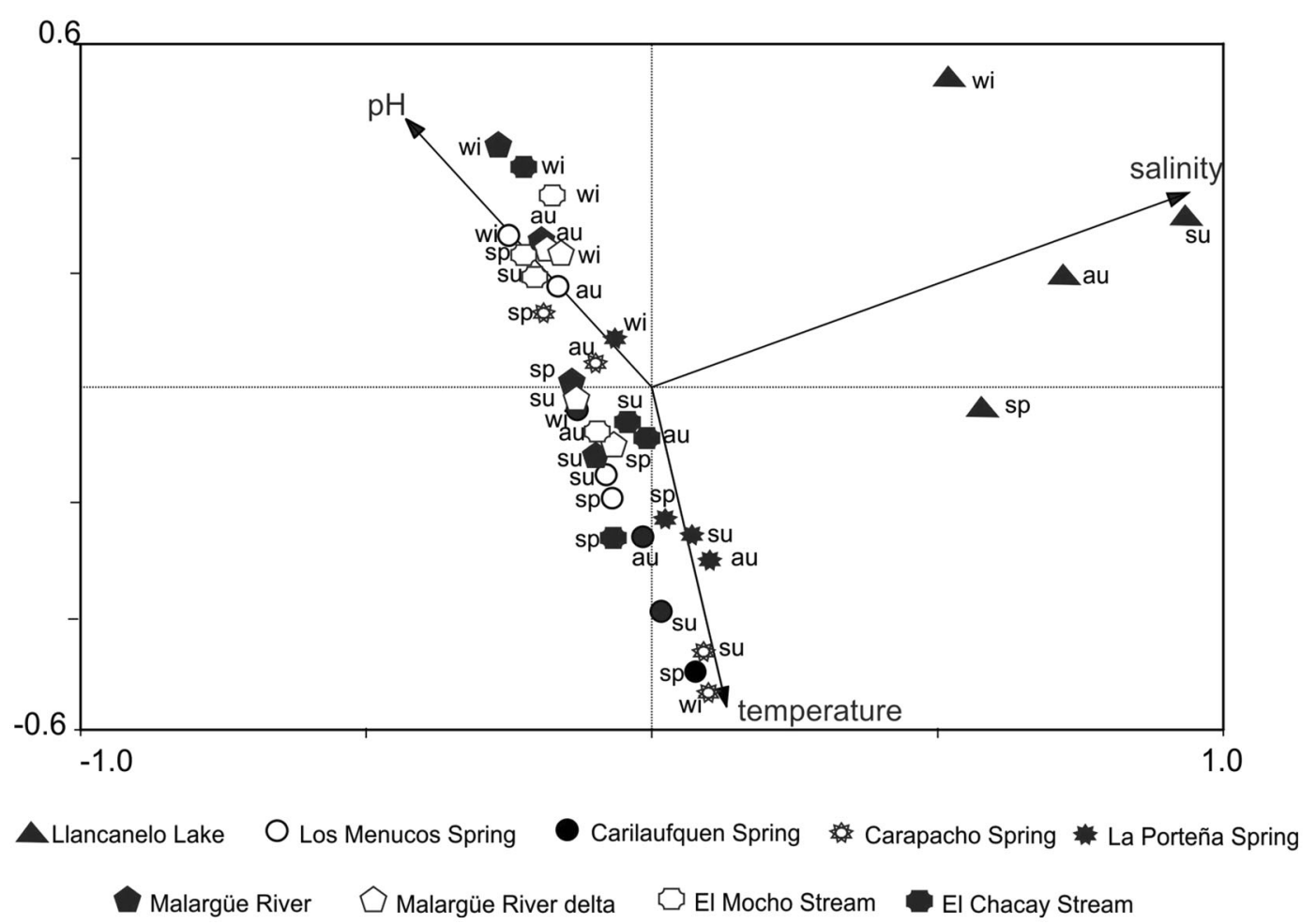

Fig. 5 Redundancy-analysis-ordination plots for the first two dimensions of the relationship between the sampling sites and the environmental variables in the Llancanelo basin ( $s p$ spring, $s u$ summer, $a u$ autumn, wi winter)

\section{Discussion}

The number of species registered in the Llancanelo Lake in this work coincides with previous findings from shallow lakes of the Puna region of this country (Locascio de Mitrovich et al. 2005) and from the saline lakes of Chile (De los Ríos and Contreras 2005).

In the Llancanelo Lake, the majority of the species recorded were halophiles, and most produced resting cysts in the sediments. Only a reduced number of zooplankton cysts hatch even during optimal environmental conditions; whereas a persistent egg bank remains viable in the sediments for many years (Radzikowski 2013), and there at an abundance that greatly exceeds that of the zooplankters in the water column (Moscatello and Belmonte 2009). Some species were found only in the lake-such as B. poopoensis, it preferring shallow saline environments of South America (Menú Marque et al. 2000; De los Ríos and Crespo 2004; De los Ríos and Contreras 2005; Bayly and Boxshall 2009; De los Ríos-Escalante 2011). The salinity values (18-40 $\mathrm{g} \mathrm{L}^{-1}$ ) recorded in the lake fall within the range of the tolerance levels given by De los Ríos (2005) for populations found in lakes located in and around the Chilean Andes and by De Los Ríos Escalante and Gajardo (2010) for the saline lakes of the South American High Plateau. Species of the genus Boeckella replace diaptomids in the southernmost part of South America (Margalef 1983), mainly in areas where calanoids have not been subjected to pressure from planktivorous fish (Hulbert et al. 1986). The low abundance but high frequency of the adults of $B$. poopoensis may be linked to the presence of the predator Phoenicopterus chilensis (the austral flamingo) (Locascio of Mitrovich et al. 2005; Bayly and Boxshall 2009; Battauz et al. 2013). The hypersaline ciliate $F$. salina was abundant in the lake, with a summer peak (at a salinity $33.5 \mathrm{~g} \mathrm{~L}^{-1}$ ) corresponding to the species's euryplasty (Pandey and Yeragib 2004) and extremophilia - as revealed by the physiologic capability of living in high salinity (Elloumi et al. 2006) and its capacity of cyst formation under unfavorable conditions (De Winter and Persoone 1975). The rare ciliate T. trisulca was also found in summer, having being recorded before in the Neotropical Region in only a temporary pond of the Buenos Aires province (Küppers et al. 2006). The presence of the dinoflagellate P. achromaticum was related to its preference for high salinity and neutral-to-alkaline $\mathrm{pH}$ (Boltovskoy 1999). Brachionus plicatilis was 


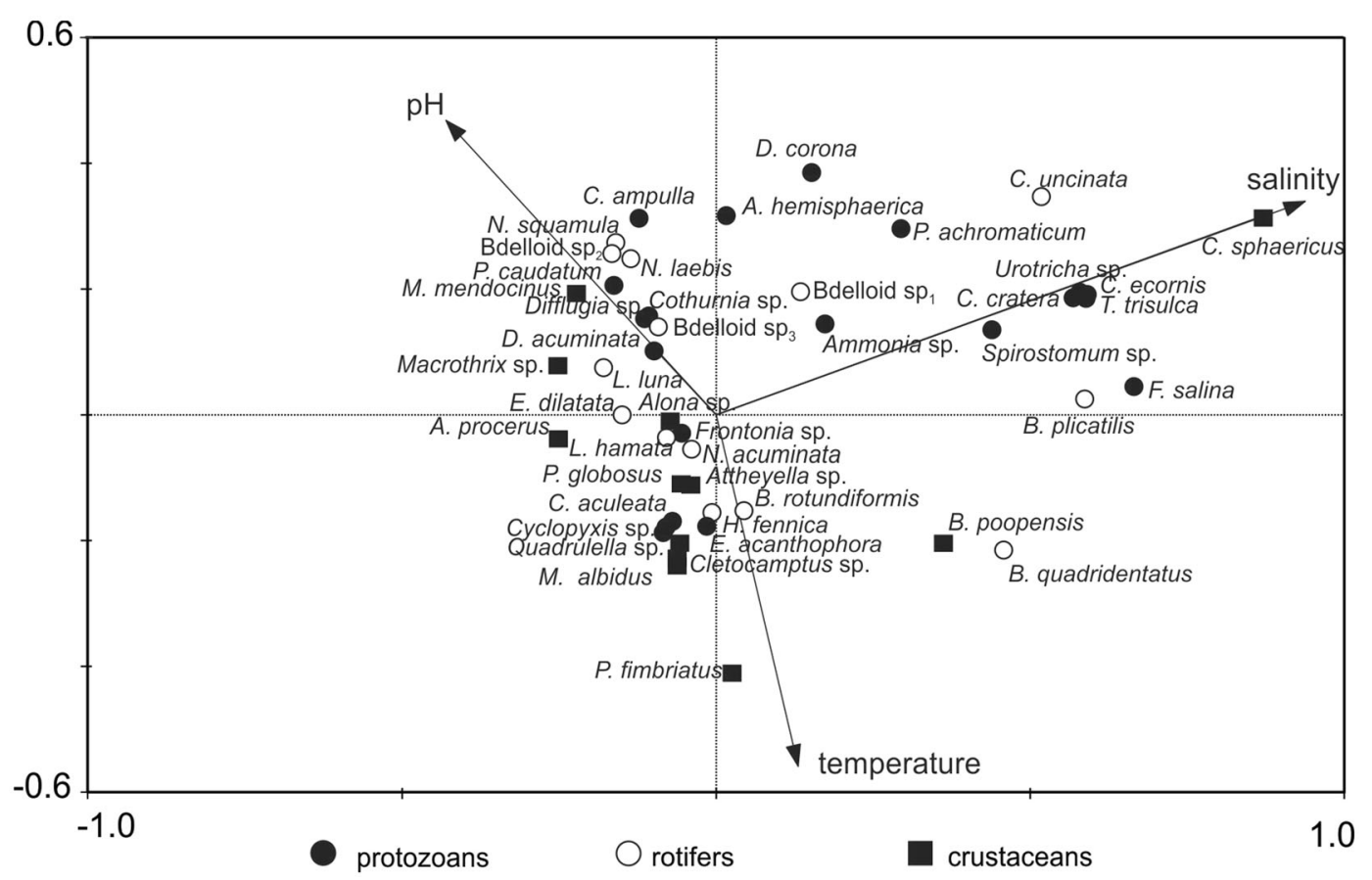

Fig. 6 Redundancy-analysis-ordination plots for the first two dimensions of the relationship between the zooplankton species (solid circle protozoans, open circle rotifers, solid square crustaceans) and the environmental variables in the Llancanelo basin

abundant in the lake because of the euryhaline propensity that enables this species to replace other Brachionus members in fluctuating saline environments (Kipriyanova et al. 2007). In Llancanelo Lake, the abundance peak of $B$. plicatilis occurred in summer along with the highest temperature and salinity values, when the conditions were optimal for the species (Fielder et al. 2000). The diversity of aquatic communities decreases with increasing salinity in salt lakes (Williams 1998; Pinder et al. 2005; Timms 2009; Tavsanoglu et al. 2015). In the present study, the influence of salinity on the decrease in zooplankton diversity (Vignatti et al. 2012) was evidenced in the lake during the seasons characterized by the highest salt content and temperature. Moreover, under those environmental conditions, the evenness became the lowest because of the dominance of few species.

In the springs, the majority of the species recorded were cosmopolitan-e.g., A. hemisphaerica (MaiaBarbosa et al. 2008), P. globosus (Smirnov 1996) and M. albidus (Frisch et al., 2006) - and usually associated with aquatic macrophytes. In addition, species with tolerance to high salinity-such as B. rotundiformis, $B$. plicatilis (Bielańska-Grajner and Cudak 2014), and P. fimbriatus (Riato et al. 2014)—were recorded at a high abundance in summer when temperatures were optimal for their population development. In the springs, the values of the diversity index were similar over the seasons, thus reflecting the more stable environmental conditions of these aquatic systems with respect to the saline lake during the year. A diminution in the number of species in those aquatic communities linked to high salinity had been noted by Peralta and Fuentes (2005) and Scheibler and Ciocco (2011) in their investigations performed exclusively at the Carilauquen spring. These last authors also included data on the hydrologic variability as a negative influence on the zoobenthic assemblages that they analyzed. In comparison to the results obtained by Peralta and Fuentes (2005) for the Carilauquen Spring, an impoverishment in species richness and abundance was observed in this same spring during the present study, though similar values of salinity obtained. Nevertheless, certain species, such as $A$. hemisphaerica and P. fimbriatus, maintained their numerical predominance.

In the lotic environments, the highest values for the diversity index were recorded during autumn and winter, with both of those periods being characterized by a lower degree of hydrologic instability along with the lowest temperatures. This thermal condition facilitated the predominance of particular biota, such as the Notholca species that were by nature stenotherms. In spite of the tolerance to salinity previously reported for 
N. acuminata (Walsh et al. 2008) and N. labis (de Manuel Barrabin 2000), these species remained exclusive to the lotic environments.

The zooplankton assemblages in the springs and lotic environments were similar because of the comparable physicochemical characteristics of those environments as common freshwater wetlands. In contrast, those species recorded in the lake evidenced their halophilic nature.

In summary, the zooplankton species richness within the entire Llancanelo area was low because of the characteristics of each aquatic environment, such as the high salinity in the lake and the uniform environments in the springs (i.e., similar water levels and a narrow range of salinity during all seasons). In addition, the hydrologic variability throughout the annual cycle within all the environments under study had a crucial influence on the impoverishment of the zooplankton community as a whole. Furthermore, in spite the absence of fish, a salient characteristic of this wetland system, the predation by birds and specific members of the community has a structuring role on the zooplankton assemblages present. The austral flamingo, for example, selectively impacts on crustaceans (Hulbert et al. 1986), while predation is also exerted by members of the zooplankton community-namely, the ciliate T. trisulca that consumes small rotifers and calanoid and cyclopoid copepods that prey on ciliates, small rotifers, and nauplii. In agreement with results in similar environments (Echaniz et al. 2006), this predation pressure on specific zooplankters of this wetland system could also facilitate the dominance of a larger rotifer (B. plicatilis).

Finally, in agreement with De los Ríos Escalante and Gajardo (2010) we consider that an increase in investigations on the zooplankton in South-American saline lakes, such as the Llancanelo-wetlands system, is urgently necessary in view of the current ongoing global climate change. According to Strecker et al. (2004) and Sommer et al. (2012), warmer temperatures could negatively affect zooplankton structure, especially in unproductive ecosystems, because of the influence of strong synergistic interactions between thermal stress and food limitation on the growth and reproduction of mainly the cladocerans. Within this scenario, eurythermal species such as certain rotifers and copepods could prevail in the absence of competition for food (Wagner and Adrian 2011). In the Llancanelo-wetland system, certain Brachionus species and cyclopoid copepods could possibly expand their predominance spatially and temporally under such conditions. As has been indicated in other aquatic ecosystems in the world (Brucet et al. 2009a, b), global warming will possibly also effect an increase in the salinity of the springs and the lotic environments within the Llancanelo basin so as to cause losses in zooplankton biodiversity as a result of the consequent reduction in the viability and longevity of the egg banks of certain freshwater species within the sediments (Nielsen et al. 2003; Nielsen and Brock 2009), thus promoting the replacement of those species by euryhaline and eurythermal biota (Toruan 2012) having preferences for high temperatures and salinity-i.e., certain species of Brachionus or B. poopoensis (De los Ríos and Crespo 2004; De los Ríos 2005).

An increase in our understanding of the zooplankton assemblages and their individual responses to elevated salinity will provide a useful tool for estimating the vulnerability to salt stress of the resident species within this conservation wetland. Furthermore, in order to comply with the mandate to protect the Llancanelo Lake (stemming from the Ramsar convention), an increase in the monitoring of these ecosystems will be necessary in order to take steps toward the management and protection of that environment.

Acknowledgments The authors wish to thank Fabricio Ayala for his invaluable help in the field, Dirección de Recursos Naturales de la Provincia de Mendoza for facilitating the research on this Ramsar site. We also thank the 4 anonymous reviewers for the constructive suggestions and comments aimed at the improvement of the manuscript. This work was supported by a grant from the Agencia Nacional de Promoción Científica y Tecnológica, FONCYT (Argentina) (Grant Raíces 2006-PICT 1311). Dr. Donald F. Haggerty, a retired academic career investigator and native English speaker, edited the final version of the manuscript.

Open Access This article is distributed under the terms of the Creative Commons Attribution 4.0 International License (http:// creativecommons.org/licenses/by/4.0/), which permits unrestricted use, distribution, and reproduction in any medium, provided you give appropriate credit to the original author(s) and the source, provide a link to the Creative Commons license, and indicate if changes were made.

\section{References}

Battauz YS, José de Paggi SB, Paggi JC, Romano M, Barberis I (2013) Zooplankton characterisation of Pampean saline shallow lakes, habitat of the Andean flamingoes. J Limnol 72:531-542. doi:10.4081/jlimnol.2013.e44 
Bayly IAE (1992) Fusion of the genera Boeckella and Pseudoboeckella (Copepoda) and revision of their species from South America and sub-Antartic islands. Rev chil hist nat 65:17-63

Bayly IA, Boxshall GA (2009) An all-conquering ecological journey: from the sea, calanoid copepods mastered brackish, fresh, and athalassic saline waters. Hydrobiologia 630:39-47. doi:10.1007/s10750-009-9797-6

Bielańska-Grajner I, Cudak A (2014) Effects of salinity on species diversity of rotifers in anthropogenic water bodies. Pol J Environ Stud 23:21-28

Blanco DE (1999) Los humedales como hábitat de aves acuáticas. Tópicos sobre humedales subtropicales y templados de Sudamérica. Oficina Regional de Ciencia y Tecnología de la UNESCO para América Latina y el Caribe-ORCYTMontevideo-Uruguay, pp 219-228

Blendinger PG, Álvarez ME (2002) Ensambles de aves de los bañados de Carilauquen (laguna Llancanelo, Mendoza, Argentina): consideraciones para su conservación. Hornero 17:71-83

Boltovskoy A (1999) Contribución al conocimiento de los dinoflagelados de la República Argentina. Tesis Doctoral 716. La Plata: Facultad de Ciencias Naturales y Museo, Universidad Nacional de La Plata

Brucet S, Boix D, Gascón S, Sala J, Quintana XD, Badosa A, Søndergaard M, Lauridsen TL, Jeppesen E (2009a) Species richness of crustacean zooplankton and trophic structure of brackish lagoons in contrasting climate zones: north temperate Denmark and Mediterranean Catalonia (Spain). Ecography 32:692-702. doi:10.1111/j.1600-0587.2009.05823.x

Brucet S, Boix D, Quintana XD, Jensen E, Nathansen LW, Trochine C, Meerhoff M, Gascón S Jeppesen E (2009b) Factors influencing zooplankton size structure at contrasting temperatures in coastal shallow lakes: implications for effects of climate change. Limnol Oceanogr 55: 1697-1711. doi:10.4319/lo.2010.55.4.1697

Bruniard ED (1982) La diagonal árida argentina: un límite climático real. Rev Geográfica 95:5-20

Ciocco NF, Scheibler EE (2008) Malacofauna of the littoral benthos of a saline lake in southern Mendoza, Argentina. Fundam Appl Limnol 172:87-98. doi:10.1127/1863-9135/2008/0172-0087

D'Ambrosio DS, Díaz AR, García A, Claps MC (2015) First description of the soft part anatomy of Ilyocypris ramirezi Cusminsky and Whatley (Crustacea, Ostracoda) from Argentina, South America. Zootaxa 3957:59-68. doi:10.11646/ zootaxa.3957.1.4

Darrieu CA, Martínez MM, Soave GE (1989) Estudio de la Avifauna de la Reserva Provincial Llancanelo, Mendoza. III. Nuevos Registros de Nidificación de Aves Acuáticas (Podicipepidae, Threskiornithidae, Anatidae, Rallidae, Laridae). Rev Asoc Ciencias Nat Lit 20:81-90

De los Ríos P (2005) Richness and distribution of zooplanktonic crustacean species in Chilean Andes Mountains and southern Patagonia shallow ponds. Pol J Environ Stud 14:817-822

De los Ríos P, Contreras P (2005) Salinity level and occurrence of centropagid copepods (Crustacea, Copepoda, Calanoida) in shallow lakes in Andes Mountains and Patagonian plains, Chile. Pol J Ecol 53:445-450

De los Ríos P, Crespo JE (2004) Salinity effects on the abundance of Boeckella poopoensis (Copepoda, Calanoida) in saline ponds in the Atacama Desert, northern Chile. Crustaceana 77:417-423

De los Ríos Escalante P (2011) Morphological variations in Boeckella poopoensis (Marsh, 1906) (Copepoda, Calanoida) in two shallow saline ponds (Chile) and potential relation to salinity gradient. Int J Aquat Sci 2:80-87

De los Ríos Escalante P, Gajardo G (2010) A null model to explain zooplankton species associations in saline lakes of the South American Altiplano (14-27S). Crustaceana 83:769-777. doi:10.1163/001121610X498764

de Manuel Barrabin J (2000) The rotifers of Spanish reservoirs: ecological, systematical and zoogeographical remarks. Limnnetica 19:91-167

De Winter F, Persoone G (1975) Preliminary culture experiments with the ciliate Fabrea salina as a potential live food for mariculture purposes. In: Persoone G, Jaspers E (eds) Proceedings of 10th European symposium on marine biology. Mariculture Universal Press, Wetteren, pp 37-48

Derry AM, Prepas EE, Hebert PDN (2003) A comparison of zooplankton communities in saline lakewater with variable anion composition. Hydrobiologia 505:199-215. doi:10.1023/B:HYDR.0000007414.12566.19

Diaz HF, Markgraf V (eds) (2000) El Niño and the Southern Oscillation: multiscale variability, global and regional impacts. Cambridge University Press, Cambridge

Echaniz SA, Vignatti AM, José de Paggi S, Paggi JC, Pilati A (2006) Zooplankton seasonal abundance of South American saline shallow lakes. Internat Rev Hydrobiol 91:86-100. doi:10.1002/iroh.200510803

Elloumi J, Carrias JF, Ayadi H, Sime-Ngando T, Boukhris M, Bouaïn A (2006) Composition and distribution of planktonic ciliates from ponds of different salinity in the solar saltwork of Sfax, Tunisia. Estuar Coast Shelf Sci 67:21-29. doi:10.1016/j. ecss.2005.10.011

Fielder DS, Purser GJ, Battaglene SC (2000) Effect of rapid changes in temperature and salinity on availability of the rotifers Brachionus rotundiformis and Brachionus plicatilis. Aquaculture 189:85-99. doi:10.1016/S0044-8486(00)00369-0

Foissner W, Berger H, Schaumburg J (1999) Identification and ecology of limnetic plankton ciliates. Bavarian State Office for Water Management, Munich

Frisch D, Moreno-Ostos E, Green AJ (2006) Species richness and distribution of copepods and cladocerans and their relation to hydroperiod and other environmental variables in Doñana, south-west Spain. Hydrobiologia 556:327-340. doi:10.1007/ s10750-005-1305-z

Grospietsch T (1972) Protozoa, Testacea und Heliozoa. In: Bick H, Breitig G, Grospietsch T, Holmquist H (eds) Das Zooplankton der Binnengewasser, E. Schweizerbart'sche Verlagsbuchhandlung, Stuttgart, pp 1-30

Gyllström M, Hansson LA (2004) Dormancy in freshwater zooplankton: induction, termination and the importance of benthicpelagic coupling. Aquat Sci 66:274-295. doi:10.1007/s00027-004-0712-y

Heino J, Virkkala R, Toivonen H (2009) Climate change and freshwater biodiversity: detected patterns, future trends and adaptations in northern regions. Biol Rev 84:39-54. doi:10.1111/j.1469-185X.2008.00060.x 
Hurlbert SH, Loayza W, Moreno T (1986) Fish-flamingo-plankton interactions in the Peruvian Andes. Limnol Oceanogr 31:457-468. doi:10.4319/1o.1986.31.3.0457

Isla FI, Ruiz Barlett E, Márquez J, Urrutia A (2005) ENSO signal recognized by NDVI images from Llancanelo shallow lake, Mendoza, Argentina. Actas XVI Congreso Geológico Argentino, La Plata, Tomo IV: 333-338

Kaya M, Fontaneto D, Segers H, Altinda A (2010) Temperature and salinity as interacting drivers of species richness of planktonic rotifers in Turkish continental waters. J Limnol 69:297-304. doi:10.3274/JL10-69-2-11

Kipriyanova LM, Yermolaeva NI, Bezmaternykh DM, Dvurechenskaya SY, Mitrofanova EY (2007) Changes in the biota of Chany Lake along a salinity gradient. Hydrobiologia 576:83-93. doi:10.1007/s10750-006-0295-9

Koste W (1978) Rotatoria. Die Rädertiere Mitteleuropas. Bestimmungswerk begründet von Max Voigt. GebrüderBorntraeger, Berlin

Küppers GC, Lopretto EC, Claps MC (2006) Morphological aspects and seasonal changes of some planktonic ciliates (Protozoa) from a temporary pond in Buenos Aires Province, Argentina. Panam J Aquat Sci 1:74-90

Locascio de Mitrovich C, Villagra de Gamundi A, Juárez J, Ceraol M (2005) Características limnológicas y zooplancton de cinco lagunas de la Puna-Argentina. Ecol Boliv 40:10-24

Loureiro C, Castro BB, Claro MT, Alves A, Pedrosa MA, Goncalves F (2012) Genetic variability in the tolerance of natural populations of Simocephalus vetulus (Müller, 1776) to lethal levels of sodium chloride. Int J Limnol 48:95-103. doi:10.1051/ limn/2012002

Maia-Barbosa PM, Peixoto RS, Guimarães AS (2008) Zooplankton in littoral waters of a tropical lake: a revisited biodiversity. Brazil J Biol 68:1069-1078

Margalef R (1983) Limnología. Ed. Omega, Barcelona

Mason IM, Guzkowska MAJ, Rapley CG, Street-Perrott FA (1994) The response of lake levels and areas to climatic change. Clim Change 27:161-197. doi:10.1007/BF01093590

McCulloch GP, Irvine K, Eckardt FD, Bryant R (2008) Hydrochemical fluctuations and crustacean community composition in an ephemeral saline lake (Sua Pan, Makgadikgadi Botswana). Hydrobiologia 596:31-46. doi:10.1007/s10750-007-9055-8

Menú-Marque S, Morrone JJ, Locascio de Mitrovich C (2000) Distributional patterns of the South American species of Boeckella (Copepoda, Centropagidae): a track analysis. J Crustacean Biol 20:262-272. doi:10.1163/20021975-99990038

Moscatello S, Belmonte G (2009) Egg banks in hypersaline lakes of the South-East Europe. Saline Syst 5:3. doi:10.1186/1746$1448-5-3$

Nielsen DL, Brock MA (2009) Modified water regime and salinity as a consequence of climate change: prospects for wetlands of Southern Australia. Clim Change 95:523-533. doi:10.1007/s10584-009-9564-8

Nielsen DL, Brock MA, Crossle K, Harris K, Healey M, Jarosinski I (2003) The effects of salinity on aquatic plant germination and zooplankton hatching from two wetland sediments. Freshw Biol 48:2214-2223. doi:10.1046/j.1365-2427.2003.01146.x

Ostera HA, Dapeña C (2003) Environmental isotopes and geochemistry of Bañado Carilauquen, Mendoza, Argentina. Short papers-IV South American symposium on isotope geology, pp 461-464

Pandey BD, Yeragib SG (2004) Preliminary and mass culture experiments on a heterotrichous ciliate, Fabrea salina. Aquaculture 232:241-254. doi:10.1016/S0044-8486(03)00459-9

Peralta P, Fuentes V (2005) Fitobentos, fitoplancton y zooplancton litoral del bañado de Carilauquen, Cuenca de Llancanelo, Mendoza, Argentina. Limnetica 24:183-197

Pinder AM, Halse SA, McRae JM, Shiel RJ (2005) Occurrence of aquatic invertebrates of the wheatbelt region of Western Australia in relation to salinity. Hydrobiologia 543:1-24. doi:10.1007/s10750-004-5712-3

Radzikowski J (2013) Resistance of dormant stages of planktonic invertebrates to adverse environmental conditions. J Plankton Res 35:707-723. doi:10.1093/plankt/fbt032

Ramos VA, Folguera A (2011) Payenia volcanic province in the Southern Andes: an appraisal of an exceptional quaternary tectonic setting. J Volcanol Geotherm Res 201:53-64. doi:10.1016/j.jvolgeores.2010.09.008

Ramsar (2002) Informe de la Misión Ramsar de Asesoramiento. Sitio Ramsar Laguna de Llancanelo Malargüe. Mendoza República Argentina, pp 1-42

Reid J (1985) Clave de identificação e lista de referências bibliográficas para as especies continentais sulamericanas de vida livre da ordem Cyclopoidea (Crustacea, Copepoda). Bol Zool Univ São Paulo 9:17-143

Riato L, Van Ginkel C, Taylor JC (2014) Zooplankton and diatoms of temporary and permanent freshwater pans in the Mpumalanga Highveld region, South Africa. Afr Zool 49:113-127. doi:10.1080/15627020.2014.11407624

Schallenberg M, Hall CJ, Burns CW (2003) Consequences of climate-induced salinity increases on zooplankton abundance and diversity in coastal lakes. Mar Ecol Prog Ser 251:181-189. doi:10.3354/meps251181

Scheibler EE, Ciocco NF (2011) Distribution of macroinvertebrate assemblages along a saline wetland in harsh environmental conditions from Central-West Argentina. Limnologica 41:37-47. doi:10.1016/j.limno.2010.03.001

Scheibler EE, Ciocco NF (2013) Diversity of aquatic insects and other associated macroinvertebrates in an arid wetland (Mendoza Province, Argentina). Rev Soc Entomol Argent 72:41-53

Segers H (1995) Rotifera: the Lecanidae (Monogononta). In: Dumont H (ed) Guides to the Identification of the Microinvertebrates of the Continental Waters of the World 6. SPB Academic Publishing, The Hague, pp 1-226

Shiel RJ, Costelloe JF, Reid JR, Hudson P, Powling J (2006) Zooplankton diversity and assemblages in arid zone rivers of the Lake Eyre Basin, Australia. Mar Freshw Res 57:49-60. doi:10.1071/MF05101

Smirnov NN (1996) Cladocera: the Chydorinae and Sayciinae. In: Dumont H (ed) Guides to the identification of the microinvertebrates of the continental waters of the World 11. SPB Academic Publishing, The Hague, pp 1-197

Sokal RR, Rohlf FJ (1979) Biometría. H. Blume, Madrid

Sommer U, Adrian R, Bauer B, Winder M (2012) The response of temperate aquatic ecosystems to global warming: novel insights from a multidisciplinary project. Mar Biol 159:2367-2377 
Sosa HJ (1995) Actualización de la lista de avifauna de la Reserva Provincial Laguna Llancanelo, Malargüe, Mendoza. Presencia estacional, preferencia de hábitat y nidificación. Multequina 4:65-75

Sosa HJ (1999) Descripción del evento reproductivo del flamenco austral (Phoenicopterus chilensis) en laguna Llancanelo, Malargüe, Mendoza. Multequina 8:87-99

Stoks R, Geerts AN, De Meester L (2014) Evolutionary and plastic responses of freshwater invertebrates to climate change: realized patterns and future potential. Evol Appl 7:42-55. doi:10.1111/eva.12108

Strecker AL, Cobb TP, Vinebrooke RD (2004) Effects of experimental greenhouse warming on phytoplankton and zooplankton communities in fishless alpine ponds. Limnol Oceanogr 49:1182-1190. doi:10.4319/1o.2004.49.4.1182

Tavsanoglu UN, Maleki R, Akbulut N (2015) Effects of salinity on the zooplankton community structure in two maar lakes and one freshwater lake in the Konya closed basin, Turkey. Ekoloji 24:25-32. doi:10.5053/ekoloji.2015.944

ter Braak CJF (1986) Canonical correspondence analysis: a new eigenvector technique for multivariate direct gradient analysis. Ecology 67:1167-1179. doi:10.2307/1938672

ter Braak CJF, Smilauer P (1998) CANOCO Reference Manual and Canoco Draw for Windows User's Guide: Software for Canonical Community Ordination (Version 4.5). Microcomputer Power, Ithaca

ter Braak CJF, Verdonschot PFM (1995) Canonical correspondence analysis and related multivariate methods in aquatic ecology. Aquat Sci 57:255-289. doi:10.1007/BF00877430

Timms BV (2009) A study of the salt lakes and salt springs of Eyre Peninsula, South Australia. Hydrobiologia 626:41-51. doi:10. 1007/s10750-009-9736-6

Toruan RL (2012) Zooplankton community emerging from fresh and saline wetlands. Ecohydrol Hydrobiol 12:53-63. doi:10. 2478/v10104-012-0003-5

Vignatti A, Echaniz S, Martín MC (2007) El zooplancton de tres lagos someros de diferente salinidad y estado trófico en la región semiárida pampeana (Argentina). Gayana (Concepción) 71:34-48. doi:10.4067/S0717-65382007000100005

Vignatti A, Festa R, Cabrera G, Echaniz S (2012) Comparación luego de una década de parámetros limnológicos, riqueza y abundancia del zooplancton de una laguna salina de la Provincia de la Pampa. BioScriba 5:23-35

Villalba R (2007) Tree-ring evidence for tropical-extratropical influences on climate variability along the Andes in South America. PAGES News 15:23-25

Vuille M, Bradley RS, Keimig F (2000) Interannual climate variability in the central Andes and its relation to tropical Pacific and Atlantic forcing. J Geophysical Res 105:12447-12460

Wagner C, Adrian R (2011) Consequences of changes in thermal regime for plankton diversity and trait composition in a polymictic lake: a matter of temporal scale. Freshw Biol 56:1949-1961

Walsh EJ, Schröder T, Wallace RL, Ríos-Arana JV, Rico-Martínez R (2008) Rotifers from selected inland saline waters in the Chihuahuan Desert of México. Saline Syst 4:7. doi:10.1186/1746-1448-4-7

Wells JBJ (2007) An annotated checklist and keys to the species of Copepoda Harpacticoida (Crustacea). Zootaxa 1568:1-872

Wen Z, Mian-Ping Z, Xian-Zhong X, Xi-Fang L, Gan-Lin G, Zhi-Hui H (2005) Biological and ecological features of saline lakes in northern Tibet, China. Hydrobiologia 541:189-203. doi:10.1007/s10750-004-5707-0

Williams WD (1998) Salinity as a determinant of the structure of biological communities in salt lakes. Hydrobiologia 381:191-201. doi:10.1023/A:1003287826503

Williamson CE, Saros JE, Warwick FV, Smol JP (2009) Lakes and reservoirs as sentinels, integrators, and regulators of climate change. Limnol Oceanogr 54:2273-2282. doi:10.4319/lo.2009.54.6_part_2.2273 